\title{
Democratic Utopias: The Argentine Transition to Democracy through Letters, 1983-1989
}

\begin{abstract}
T a correspondencia en sí misma ya es una forma de la utopía. Escribir una carta es enviar un mensaje al futuro; hablar desde el presente con un destinario que no está abí, del que no se sabe cómo ha de estar (en qué ánimo, con quién) mientras le escribimos y sobre todo, despues: al leernos. La correspondencia es la forma utópica de la conversación porque anula el presente y hace del futuro el unico lugar posible del diálogo.
\end{abstract}

- Ricardo Piglia

On May 1, 1989, María, a high school teacher from Buenos Aires, wrote a letter to President Raúl Alfonsín as he began his final months in office. The country was in the midst of a hyperinflation crisis and elections were set for just two weeks away. Earlier in the day, María had heard the president's last address to the congress, and she felt compelled to write him. "My friend," she began, as she recounted how she and her husband, an adjunct university instructor, had worked hard over two decades of marriage, weathering continuous financial difficulties and the sensation of "always having to start over." María emphasized that she had no political affiliations that would cloud her judgment, lest the president think she was writing to ask for political favors.

She recalled her happiness at casting her vote for Alfonsín in 1983 after seven years of military dictatorship. Though she said she did not regret the decision, she was barely able to mask her exasperation when she asked, "But why did you take away our hopes . . . why did you abandon us?" After mentioning her adolescent daughters and her concerns about their desires to quit their studies and leave Argentina, she concluded her letter with a mix of appreciation and resignation: "So no matter, Mr. President, thank you, thank you so much 
for helping me recover my dreams and hopes in 1983, and thank you for the democracy that allows me to live and to write you this letter, even though it does not allow for me to get sick."

María's letter offers a glimpse into the lived experience of Argentina's "transition to democracy." Her letter narrates intimate details of personal and family history and weaves them into the broader social expectations that accompanied constitutional restoration. This article examines letters sent to the president during Argentina's democratic transition, which corresponds roughly to the government of Raúl Alfonsín (1983-1989). Alfonsín's election in October 1983 heralded the return of democratic rule and the end of the nation's most brutal period of military dictatorship (1976-1983), in which up to 30,000 people were disappeared. Alfonsín was a leading member of the Radical Civic Union party (UCR). His election, the first many Argentines could remember that was not marred by violence or exclusion, not only signaled the return to democracy but also marked the first electoral defeat of Peronism in its forty year history. Over the course of the 1980s, thousands of Argentines saw the democratic opening as the opportunity to write unsolicited letters to the president, and their messages inspire reevaluations of the history of Latin America's democratic restorations.

Until recently, investigations of this period have been dominated by studies that analyze Latin America's democratic transitions as guided by government elites, electoral politics, and military trials. ${ }^{2}$ The personal letters examined here take place between and around the headlines of the most dramatic institutional moments. As such, they complicate the very notion of a "democratic transition"

1. The letters on which this article is based are housed in the Archivo General de la Nación/Departamento Archivo Intermedio [hereafter AGN/DAI], Fondo Documental "Presidencia de la Nación. Secretaria Privada (19831989)." I have omitted the last names of letter writers to protect their identities. Though Raúl Alfonsín received letters from all over the country, the letters analyzed in this article were sent from Buenos Aires and the surrounding suburbs. Unless otherwise noted, all translations are mine. AGN/DAI "Presidencia Alfonsín," leg. 273-152.850.

2. For the purposes of this article, the period of democratic restoration in South America refers specifically to the return of democratic governments in Argentina (1983), Brazil (1985), Uruguay (1985), Paraguay (1989), and Chile (1990). Classic works on democratic transitions in South America include Transitions from Authoritarian Rule, a fivevolume Woodrow Wilson Center series edited by Guillermo O'Donnell, Philippe Schmitter, and Laurence Whitehead, published in 1986. See as well Juan Linz and Alfred Stepan, Problems of Democratic Transitions and Consolidation: Southern Europe, South America, and Post-Communist Europe (Baltimore: The Johns Hopkins University Press, 1988); and Guillermo O'Donnell, Counterpoints: Selected Essays on Authoritarianism and Democratization (Notre Dame: University of Notre Dame Press, 1999). More than analyses of Southern Cone political transformations, these studies, formulated throughout the 1970s, 1980s, and 1990s by many of the leading political scientists of Latin America, Europe, and the United States, constituted "guideposts" for the direction of political change. Intellectual production from within the social sciences-in particular sociology and political science-represents an integral part of the history of the era. For an investigation of the historical role of this literature, the political scientist Cecilia Lesgart has reconstructed the "idea" of the democratic transition. She follows a group of Chilean and Argentine social scientists and intellectuals and examines how their formulations came to occupy a central role throughout the 1980s. See Lesgart, Usos de la transición a la democracia: ensayo, ciencia y política en la década del '80 (Buenos Aires: Ediciones Homo Sapiens, 2005). 
by grounding political transformation in the quotidian realms of family, neighborhood, and marketplace, among others. Though writers filled their letters with details of the changes that accompanied the end of military rule in Argentina, they did so in dialogue with past political frameworks and with an eye toward an uncertain future. Based on a close reading of approximately 5,000 letters to the president, this article makes the central argument that Latin America's democratic openings in the 1980s constituted a new phase in the ongoing struggle to define the contours of democracy and citizenship, one that dominated the course of the twentieth century. ${ }^{3}$

What compelled Argentines to write to the president? Who wrote? What did they hope to achieve? And what is the significance of the correspondence? These questions have guided investigations of the epistolary tradition in Latin America since the colonial period, with historians mining letters to derive understandings of popular culture, national sentiment, and government administration, among others. ${ }^{4}$ During the twentieth century, an era characterized by growing literacy rates, letter-writing has been frequently analyzed as evidence of popular political participation. Sueann Caulfield relies on the correspondence of Rio de Janeiro's popular classes to argue for the centrality of concepts of honor and virtue in the making of modern Brazil. ${ }^{5}$ Joel Wolfe's investigation of letters to Getúlio Vargas focuses on the critical role of the working class in the evolution of varguismo and contested national

3. For a brief overview of works that frame the history of twentieth-century Latin America as a struggle over the definition of citizenship and democracy, see in particular Ian Roxborough, "Unity and Diversity in Latin American History," Journal of Latin American Studies 16:1 (May 1984) pp. 1-26; Daniel James, "Uncertain Legitimacy: The Social and Political Restraints Underlying the Emergence of Democracy in Argentina, 1890-1930," in The Social Construction of Democracy, 1870-1990, George Reid Andrews and Herrick Chapman, eds. (New York: New York University Press, 1995), pp. 56-70; Steve Stern, "Between Tragedy and Promise: The Politics of Writing Latin American History in the Late Twentieth Century," in Reclaiming the Political in Latin American History: Essays from the North, Gilbert M. Joseph, ed. (Durham: Duke University Press, 2001), pp. 32-77; and Greg Grandin, The Last Colonial Massacre: Latin America in the Cold War, 2nd ed. (Chicago: University of Chicago Press, 2011).

4. Specific studies on the history and practice of letter writing have focused largely on the colonial period through the nineteenth century. See for example John Lockhart and Enrique Otte, Letters and People of the Spanish Indies, Sixteenth Century (Cambridge: Cambridge University Press, 1976); and John Lockhart's essay, "Letters and People to Spain," in his Of Things of the Indies: Essays Old and New In Early Latin American History (Stanford: Stanford University Press, 1999), pp. 81-97. More recently, Kathryn Burns has looked at the politics of writing in Into the Archive: Writing and Power in Colonial Peru (Durham: Duke University Press, 2010). For the nineteenth century, scholars have examined letter-writing as an integral part of nation-building. Key works in this regard include Ángel Rama, The Lettered City, John Chasteen, trans. and ed. (Durham: Duke University Press, 1996); Sarah Chambers, "Letters and Salons: Women Reading and Writing the Nation in the Nineteenth Century," in Beyond Imagined Communities: Reading and Writing the Nation in Nineteenth-Century Latin America, Sarah Castro-Klarén and John Chasteen, eds. (Baltimore: John Hopkins University Press, 2003), pp. 54-83; and William French, "'Cartas y cartas, compadre ... ': Love and Other Letters from Río Frío," in Latin American Popular Culture since Independence, 2nd ed., William H. Beezley and Linda Ann Curcio, eds. (Lanham, Md.: Rowman \& Littlefield, 2012), pp. 68-84.

5. Sueann Caulfield, In Defense of Honor: Morality, Modernity, and Nation in Early Twentieth-Century Brazil (Durham: Duke University Press, 2000). 
imaginaries. ${ }^{6}$ Wolfe's findings are echoed by Lauren Derby, whose analysis of denunciations in Dominican newspapers frames letter-writing as a democratic exercise that offered ways to circumvent the authoritarianism of the Trujillo regime. ${ }^{7}$

Building on these interventions, this article analyzes public letter writing as a political act, wherein the boundaries between supplicant and leader are blurred and where the dynamics of citizenship and state-making are at their most vivid. It argues for the ongoing importance of letter-writing as a popular cultural and political practice that endured through the end of the twentieth century, a period that has received relatively little attention compared to earlier epistolary histories. ${ }^{8}$ During the 1980 s, correspondence positioned individuals as both participants in and architects of the new democracy. The messages reflect a prolonged moment of political change, distilled through personal experience and emotion, which reveal the shifting social meanings of the very transition to democracy.

In the case of contemporary Argentina, two instances of letter-writing locate the petitions to Alfonsín within longer-lived historical contests in the realms of rights and citizenship. Eva Perón, through her foundation, received thousands of letters daily with requests for material assistance and financial support. In his classic study of the cultural life of Peronist Argentina, Mariano Plotkin argues that the letters brought citizens closer to an "easily accessible center of power." Sending a petition to the Eva Perón Foundation was the way to obtain gifts, material support, and inclusion into the robust welfare state of the day. More recently, Eduardo Elena's examination of the public letter-writing campaign "Perón Wants to Know," in the context of Perón's second Five-Year Plan, illuminates popular engagement with Peronist discourse and the history of state planning. ${ }^{10}$ In both cases, the letters to Perón and Evita evidence expanding

6. Joel Wolfe, "Father of the Poor or Mother of the Rich? Getúlio Vargas, Industrial Workers, and Constructions of Class, Gender, and Populism in São Paulo, 1930-1954," Radical History Review 58 (Winter 1994), pp. 80-111. See as well Brodwyn Fisher's examination of letters to Vargas in A Poverty of Rights: Citizenship and Inequality in Twentieth-Century Rio de Janeiro (Stanford: Stanford University Press, 2008).

7. Lauren Derby, "In the Shadow of the State: The Politics of Denunciation and Panegyric During the Trujillo Regime in the Dominican Republic, 1940-1958," Hispanic American Historical Review 83:2 (May 2003), pp. 295344 .

8. For a notable exception see Adolfo Gilly and Rhina Roux, eds., Cartas a Cuaubtémoc Cárdenas (Mexico: Colección Problemas de México, Ediciones Era, 1989).

9. Mariano Plotkin, Mañana es San Perón: A Cultural History of Perón's Argentina (Wilmington, Del.: Scholarly Resources Inc., 1993), p. 158.

10. Eduardo Elena, "What the People Want: State Planning and Political Participation in Peronist Argentina," Journal of Latin American Studies 37:1 (February 2005), pp. 81-108. Omar Acha has also investigated the letters to Perón as evidence of the creation of a distinctly new political society. See Acha, "Sociedad civil y sociedad política durante el primer peronismo,” Desarrollo Económico 44:174 (July-September 2004), pp. 199-230. 
notions of citizenship, and the redefinition of democracy along emancipatory and social lines by mid-century. ${ }^{11}$

With this history in mind, the correspondence to Alfonsín is neither unique nor unprecedented. The letters often evoke the language and forms associated with clientelism, with writers frequently intimating promises of their political support in exchange for material assistance. ${ }^{12}$ Letter-writers of the $1980 \mathrm{~s}$ echoed the concerns of petitioners past, from emotional pleas for employment and economic support to commentary about the course of the nation. However, clientelism alone does not fully explain the letters to Alfonsín. In contrast to earlier archives of letters from the Peronist period, those of the 1980s reflect a changing social contract between the government and its citizenry, framed by the new political constraints of economic crisis and neoliberal policy. In Argentina, as in the rest of South America, the region's constitutional restorations coincided with the worst fiscal crises since the 1930s.

Beginning with Mexico's economic default in 1982, the dawn of the new decade sparked economic changes experienced primarily in the form of social and economic emergency. And whereas in the wake of the 1930s crises Latin American governments adopted state-led welfare and development programs to ameliorate the impact of economic constriction, that approach was in full decline by the end of the twentieth century. Newly restored constitutional governments experimented with economic policies that eroded decades-old fiscal measures in favor of the gradual embrace of neoliberal structural readjustment. ${ }^{13}$ The tension at the heart of many of the letters to Alfonsín sees petitioners celebrating the democratic return while attempting to come to terms with a state that was poorly equipped in a material sense and much less capable of responding to demands for welfare and redress.

Thus, while the letters to Alfonsín hearken back to the frameworks of populist patronage forged during the Peronist period, there exist critical differences as well. Unlike the letters sent to Eva and Juan Perón, which reflect interest in a particular institution or campaign, the correspondence sent to Alfonsín is

11. Daniel James, Resistance and Integration: Peronism and the Argentine Working Class, 1946-1976 (New York: Cambridge University Press, 1988); Jeff Gould, To Lead as Equals: Rural Protest and Political Consciousness in Chinandega, Nicaragua, 1912-1979 (Chapel Hill: University of North Carolina Press, 1990).

12. My discussion of clientelism is informed by Javier Auyero's groundbreaking ethnographic study of patronclient networks in the shantytowns of Buenos Aires. In contrast to studies that emphasize the negative aspects of clientelism, Auyero examines its historical and sociological roots as a series of "informal problem-solving networks" that helps residents mitigate extreme forms of poverty and exclusion. Auyero, Poor People's Politics: Peronist Survival Networks and the Legacy of Evita (Durham: Duke University Press, 2001).

13. For a comparative look at the political economy of Latin America during the mid 1980s, see Albert O. Hirschman, "The Political Economy of Latin American Development: Seven Exercises in Retrospection," Latin American Research Review 22:3 (1987), pp. 7-36. 
at times less amenable to contextualized analysis. There was no official call to correspondence with the restoration of democracy, and the majority of letters never received any response. Yet thousands of Argentines from across the country viewed the constitutional return as the chance to write the president with their advice, complaints, and hopes for the new era. ${ }^{14}$ Argentines of all ages and walks of life wrote to Alfonsín: members of the middle and working classes, elites and impoverished individuals, and political supporters and opponents alike. Despite their diffuse range of concerns and subject matter, the epistolary archive of the Argentine transition must be read as more than the observations of random, atomized individuals. The letters from the 1980s evidence the exuberance of renewed democratic participation. They also reveal the historical questions at stake during a period that saw both government officials and citizens grappling with the consequences of simultaneous political opportunity and economic uncertainty. ${ }^{15}$

Though Alfonsín received letters from across Argentina, this article examines letters sent from Buenos Aires and the surrounding metropolitan suburbs. The correspondence analyzed here reflects the diversity of petitioners and their concerns, with attention paid to the ways that writers addressed the meaning of the democratic return in their lives. The findings in this article are based on readings of approximately 800 letters from each year of the Alfonsín presidency (1983-1989). The article first explores the democratic expectations of letter-writers during the first two years of the Alfonsín presidency (19831985), a period of widespread support for the government. It then examines the limits of national political openings through a discussion of the concepts of rights and citizenship that emerge through the correspondence. Writers from Buenos Aires relied on familiar tropes of self-presentation and political

14. The exact number of letters sent to Alfonsín over the course of his presidency is unknown, and because there has been no official attempt to systematize the correspondence, it is difficult to speak of a representative sample. While Alfonsín received thousands of letters over the course of his presidency, it is most likely that the numbers did not surpass the amount of correspondence sent to Eva and Juan Perón. Some estimate that the Eva Perón Foundation received, on average, 12,000 letters per day. Evita was famous for personally responding to letters, often meeting individually with petitioners. In contrast, as Eduardo Elena notes in his study of letters sent to Juan Perón during the "Perón Wants to Know" campaign, it was often unclear what happened to citizens' letters once they arrived at government offices. The same was true of the popular correspondence to Alfonsín, which only rarely received a response from one of his secretaries.

15. This article builds on a rich and growing body of historical scholarship that investigates Latin America at the end of the twentieth century. See for example Louise Walker's investigation of the role of the Mexican middle class in the context of economic turmoil and political upheaval. Walker, Waking from the Dream: Mexico's Middle Class After 1968 (Stanford: Stanford University Press, 2013). Her examination of the imbrications of political change and economic crisis in daily life demonstrates the emergence of a social logic that justified neoliberalism among the middle classes. In addition, the first volume of Steve Stern's Pinochet trilogy, Remembering Pinochet's Chile: On the Eve of London, 1998, offers a theoretically grounded view of the challenges of writing recent history (Durham: Duke University Press, 2004). See as well Vania Markarian, Left in Transformation: Uruguayan Exiles and the Latin American Human Rights Networks, 1967-1984 (New York: Routledge, 2005); and Bryan McCann, Hard Times in the Marvelous City: From Dictatorship to Democracy in the Favelas of Rio de Janeiro, (Durham: Duke University Press, 2014). 
posturing reminiscent of other correspondence sent to twentieth-century leaders. However, the workers, housewives, business owners, and unemployed individuals, among others, who wrote to Alfonsín often took pains to emphasize that they were above all apolitical citizens without an agenda. Writers expressed a notion of citizenship rooted in the language of human rights, the legitimizing principle of Argentina's constitutional restoration. As citizens faced the realities of impending economic reorganization, they framed their rights claims in reference to earlier definitions of a democratic benefactor state that in reality became less and less viable as the decade proceeded. The last section of the article examines the final months of the Alfonsín presidency and the ways that letter writers made explicit the vast undoing and refashioning of their democratic expectations.

\section{Democratic Horizons}

Following seven years of brutal military rule, with its legacy of torture, disappearance, and economic turmoil, Argentines celebrated the return to democracy in 1983 with euphoric hope for an era of justice and peace. Christmas cards, photos, newspaper clippings, and hastily written messages scrawled on carbon paper began arriving at the government palace immediately following Raúl Alfonsín's inauguration on December 10, 1983. In addition to congratulations and well-wishes for the new president, authors acknowledged they were witnessing an age of new beginnings. Writers described in vivid detail the discussions they were having at home, work, and school in the wake of the elections. Jorge, a 55-year-old emergency-room doctor, expressed the effervescence of the moment. "The hour of truth, justice, decency, and honesty has arrived," he began, and continued:

Argentines are proud that a simple man full of great virtues will be able to rescue this sick Argentina from its stage-four coma, as we say in medicine. You have already begun by standing firm and I can assure you that from October 30, 1983, until today I have shed many tears of joy. We have had great Radicals- H. Yrigoyen, Alem, Balbín, Illia—and now you. What happiness for our beloved Argentina! ${ }^{16}$

Jorge's letter touches on two critical details surrounding the end of military rule in Argentina. First, Alfonsín's election marked the end of 50 years of increasingly violent military takeovers that had dominated political life since the 1930s. Second, the election of Alfonsín, a leading member of the Radical Party, represented the first-ever electoral defeat of Peronism. This was a shift 
that upended the logic of mainstream Argentine politics seemingly overnight at the onset of the new democratic era. Jorge's letter conveys a sense of historic renewal, with Alfonsín passing into the pantheon of national Radical Party heroes.

The promise of 1983 did imply a decisive break with Argentina's political past. Yet, initial expectations for the Alfonsín government were also rooted in its self-conscious attempt to fulfill and reconcile the earlier democratic transitions surrounding the political movements of both Hipólito Yrigoyen and Juan Perón. Yrigoyen, the historical leader of the UCR, consolidated broad popular participation in politics at the beginning of the century. The Alfonsín government seized on the legacy of the UCR as Argentina's “oldest political party" and its reputation as the descendant of the nation's first democratic experiment to legitimize its own project for constitutional rule. ${ }^{17}$ At the same time, the Alfonsín government saw itself as a unifying force for the nation. It evoked Peronism's role in expanding the bounds of citizenship, and culled from Peronist rhetoric the principles of social and economic justice that became the foundation of its own policies. ${ }^{18}$ In the wake of the savage violence of the military dictatorship, the administration's adoption of a human rights discourse sought to bind conceptually two of the nation's leading political traditions. The triple promise of political rights, physical safety, and social well-being resonated in a country where many understood political terror and social deprivation to be bound up with one another.

Argentina's new democracy was forged amid the ruins of state terror, a legacy that encompassed not only the human rights abuses of the regime, but also a hobbled manufacturing economy and skyrocketing debt. At the start of 1984, the first full year of the Alfonsín presidency, the social and economic challenges were formidable, with estimates of 25 percent going hungry in some

17. For the history of the UCR see Ezequiel Gallo and Silvia Sigal's essay, "La formación de los partidos políticos contemporáneos - la UCR (1891-1916)," in Torcuato S. Di Tella, Gino Germani, Jorge Graciarena, et al., Argentina, sociedad de masas (Buenos Aires: EUDEBA, 1965), pp. 24-76; and David Rock, Politics in Argentina: The Rise and Fall of Radicalism, 1890-1930 (New York: Cambridge University Press), 1975. For newer histories of Radicalism, see Ana Virgina Persello, Historia del radicalismo (Buenos Aires: Edhasa, 2007); and Matthew Karush's examination of Radicalism and working-class politics in Rosario during Argentina's first "transition to democracy" (1912-1930). His study pays close attention to the class identity of new voters and participants in electoral politics, arguing that in the early twentieth century, elites attempted to use democracy and electoral politics to "efface working class identity and replace it with a neutral form of citizenship." See Karush , Workers or Citizens: Democracy and Identity in Rosario, Argentina (1912-1930), (Albuquerque: University of New Mexico Press, 2002), p. 2.

18. Alfonsín and his cohort very deliberately referred to the dawn of the democratic era as the inauguration of a "third historical movement" that would unite the two leading political movements of the twentieth century. Accordingly, this "third way" would guide the democratic restoration, leading the way through and beyond the social turmoil and military backlash that, as alfonsinistas claimed, often resulted from the corporatist labor mobilization of Peronism. See Gerardo Aboy Carlés, Las dos fronteras de la democracia argentina: la reformulación de las identidades politicas de Alfonsín a Menem. (Rosario: Homo Sapiens Ediciones, 2001). 
major metropolitan centers. ${ }^{19}$ The year was also marked by a startling annual consumer inflation rate of 688 percent, which would only increase by decade's end. ${ }^{20}$ In their depictions of daily life, writers outlined a picture of a nation emerging from dictatorship. Petitioners often paired their optimism with an awareness of the challenges that lay ahead. A letter from Martha, a homemaker and mother of three, is emblematic of the growing difficulties described by many. After "much deliberation" Martha decided to write Alfonsín in the hope that he could help her husband Mario recover his job. In 1979 he had been fired from the refinery where he had worked for almost a decade. Since then, she explained, her family had "experienced hard times, and we are still struggling." To make ends meet Mario sold veterinary supplies, driving "between 300 to 400 kilometers a day" in the family's "run-down, 1971 Renault 6." After car and housing payments, "every day more expensive," the family was barely able to cover the cost of food. Pregnant with her fourth child, Martha explained that her baby gave her the courage to write Alfonsín to ask him to reverse the "injustice committed against [Mario]," and by extension against her family. Though she knew Alfonsín "faced many challenges," she believed he could help, concluding with "Sometimes you need to push miracles a little to make them happen."21

Though the word democracy does not appear in María's letter, the future that she envisioned revealed a broad expectation that the democratic era would, to paraphrase Alfonsín's most famous campaign slogan, "heal, educate, and feed." 22 Writers put forward a panorama of need. Mothers wrote on behalf of sons to enlist them in apprenticeship programs; families implored the president's help to pay bills and to schedule visits from social workers; pensioners requested assistance to enroll in the government-sponsored housing program; and small-time entrepreneurs solicited loans to save their businesses, or to start them. These appeals may be in many ways typical of citizen petitions to leaders. In particular, they recall letters sent to the Eva Perón Foundation. However, read through the lens of restored constitutional government, the correspondence to Alfonsín takes on a specific meaning, one that connected the promise of the democratic era to the amelioration of years of want through renewed and strengthened public services and government outreach. A popular

19. Instituto Nacional de Estadística y Censos (INDEC), La pobreza en la Argentina: indicadores de necesidades básicas insatisfechas a partir de los datos del Censo Nacional de Población y Vivienda 1980 (Buenos Aires: INDEC, 1984).

20. Inflation remained high through the 1980s, with a massive spike in 1989 during several months of hyperinflation. The consumer inflation rate fluctuated throughout the decade, as the following numbers indicate: 1984: 688\%; 1985: 385\%; 1986: 81.9\%; 1987: 174.8\%; 1988: 387.7\%; and 1989: 4,923.6\%. Figures quoted from Mario Rapoport, Historia económica y política social de la Argentina, 1880-2003 (Buenos Aires: Ariel, 2006), p. 707.

21. AGN/DAI "Presidencia Alfonsín," leg. 90: 20224/84.

22. "Con la democracia se come, se cura y se educa" (With democracy, one eats, one is cured, and one is educated) was the hallmark phrase of Alfonsín's presidential campaign. 
definition of democracy comes into focus through the correspondence, which combined political openings-as expressed in letters that struck a personal relationship with the president - with a socially grounded vision of rights, collective welfare, and individual prosperity.

Whereas many petitioners wrote the president asking for material assistance, authors also wrote with a variety of proposals for what they believed Alfonsín must do to set Argentina on a new course. The volume of these letters indicates how seriously Argentines engaged with and sought participation in the course of democratic return. Some proposals were simple one-line missives: "To reactivate the economy, do the opposite of what the IMF tells you!" 23 Others were more complex, for example, a treatise on assembly-line production in the northern province of Tucumán. ${ }^{24}$ Considered together, the proposals constitute a rich lode of correspondence sent throughout the decade that is difficult to classify. However, during Alfonsín's first two years in office, the period of greatest support for the government, citizen proposals emphasized economic recovery. Enrique, a retiree from the outskirts of Buenos Aires, presented his own intricate formulas for the sale of fiscal lands, a deposit scheme to pay off public debt, and the issuing of fixed-term bonds to "end the constant flight of capital abroad." ${ }^{25}$ A man named Diego sent his sketches for a fiveyear plan to revive agricultural production "without any additional cost to the state." He was so certain of his claims that he assured the president that if he came across as a "bit loco," he would be happy to send references to vouch for his credentials. ${ }^{26}$ There were so many proposals of this sort that at one point in 1984 Alfonsín's long-time secretary, Margarita Ronco, drafted a form letter in response, thanking petitioners on behalf of the president and encouraging their ongoing support: "As [President Alfonsín] continues to face tremendous responsibilities, he will need the support of citizens like you who, with maturity and determination, secured the return of democracy." 27

Economic recovery was on the minds of many in the early 1980s. When he took office, Alfonsín faced an unprecedented debt of $\$ 43$ billion, a direct result of the open market policies adopted by the military regime. ${ }^{28}$ As many

23. AGN/DAI “Presidencia Alfonsín," leg. 33: 7636-1-003.

24. Ibid., leg. 90: 1735/84.

25. Ibid., leg. 3: 28994/84.

26. Ibid., leg. 90: 20215/84

27. This letter from Alfonsín's secretary, dated early 1984, was the only official response I encountered in the archives. It seems likely that this type of form letter was sent only during the first few months of the Alfonsín presidency, at the height of the greatest amount of support for the recently inaugurated democratic government. AGN/DAI "Presidencia Alfonsín," leg. 90: 20115/84.

28. For an overview of the state of the Argentine economy at the end of the military regime, see Klaus Veigel, Dictatorship, Democracy, and Globalization: Argentina and the Cost of Paralysis, 1973-2001 (University Park: Penn State Press, 2009). 
scholars have noted, by the late 1970s inflation had been incorporated into the everyday survival strategies of Argentines in ways that altered patterns of consumption and the nature of economic decision-making. ${ }^{29}$ Foreign debt, however, remained the purview of economists and technocrats until 1982 when Mexico's debt crisis hastened the economic collapse of the Argentine military regime and thrust the issue into the public realm as never before. Throughout 1984, the comings and goings of Bernardo Grinspun, Alfonsín's first economic minister, and his epic negotiations with the International Monetary Fund filled countless newspaper editorials and hours of evening talk shows.

In the fiscal realm, the Alfonsín administration's first economic team embraced a developmentalist agenda. Grinspun, the irascible minister, began his career as part of the Radical government of Arturo Illia (1963-1966), later forming part of Alfonsín's inner circle. The echoes of mid-1960s fiscal policy informed the administration's economic philosophy during its first year. As Grinspun described it, his top priority upon assuming his post was to "raise the factory curtains once again." 30 The reactivation of the industrial economy, the restoration of real wages, and the effort to end unemployment all aimed to reverse the economic policies of the dictatorship and at the same time to modernize the Argentine economy. Almost immediately, however, debt and the burden of inflation got in the way of those intentions.

The restructuring of the debt and the settling of payments owed proved a dicey political issue. Alfonsín proclaimed repeatedly that only the "legitimate" debt would be paid, and he authorized a congressional committee to investigate the origins of national debt. ${ }^{31}$ Any gesture toward accepting the totality of debt would have signified compliance with the economic philosophy of the recent dictatorship. In addition, there was an implicit assumption on the part of the administration that officials at the IMF and the U.S. Federal Reserve, which set global interest rates, would look favorably on Argentina as it democratized and emerged from its long night of violence. ${ }^{32}$ Argentine

29. Gabriel Kessler and Silvia Sigal, "La hiperinflación en Argentina: comportamientos y representaciones sociales," in La investigación social hoy: a cuarenta años de la recreación del Instituto de Sociología (UBA), Darío Canton and Jorge Raúl Jorat, eds. (Buenos Aires: Instituto Gino Germani y Oficina de Publicaciones del CBC, 1997), pp. 155187.

30. For more on the early fiscal policies of the Alfonsín government, see Julieta Pesce, "Política y economía durante el primer año del gobierno de Raúl Alfonsín: la gestión del ministro Grinspun," in Los años de Alfonsín: el poder de la democracia o la democracia del poder?, Alfredo Puciarelli, ed. (Buenos Aires: Siglo XXI Editores, 2006), pp. 367-412. See also Néstor Restivo and Horacio Rovelli, El accidente Grinspun: un ministro desobediente, Claves para Todos, José Nun, series editor (Buenos Aires: Capital Intelectual, 2011).

31. Raúl Alfonsín, "Hay cuentas que no cierran," December 29, 1982. Biblioteca UCR, Carpeta Alfonsín No. 1.

32. José Luis Machinea, interview [CD video recording], April 4, 2007, Archivo de Historia Oral de la Argentina Contemporánea, Programa de Historia Política del Instituto de Investigaciones Gino Germani (UBA), Centro de Documentación e Información (IIGG), Buenos Aires. 
officials encountered no such goodwill. Rumors circulated that Argentine debt would be classified as "problem loans" because the country had fallen behind on interest payments. ${ }^{33}$ Reinforcing these perceptions of economic insolvency was the fact that Grinspun did not make a good impression on Argentina's lenders. In one infamous encounter, he was rumored to have dropped his pants during a meeting at the IMF. Economic reality meant only the deepening of debt: crippling interest rates led to requests for more loans by the end of $1984 .^{34}$

Letters regarding the foreign debt poured in. Along with the specter of inflation, debt was one more legacy of authoritarianism that threatened to eclipse the return of democracy. The media covered the debt with chronicles of high-level meetings of state officials and international lending organizations, but citizens cast the social impact of debt in a different light. On the one hand, the letter-writers emphasized the burgeoning debt as a national concern, the burden of which was not yet fully known. On the other hand, unlike inflation, which writers commented on as a force beyond personal control, debt seemed a more concrete problem that could be easily resolved. Hilarina, writing from her one-room apartment in the south of Buenos Aires, declared that she and her compatriots would be willing to "donate a paycheck or a month's rent" to help pay off the debt. In this way, she concluded, "We would feel what it really means to be Argentine. And we would fulfill our duty to the nation, just like Remedios de Escalada de San Martín!"35 Patriotic fervor imbues many letters, and writers frequently signaled their desire to participate in the project of rebuilding the nation.

Schemes, proposals, and grand ideas overwhelmed the early correspondence to the president. Many writers sensed this and acknowledged that their letters might be headed for bureaucratic oblivion, often with comments like "I know this will probably never reach you." Indeed, the vast majority of letters never reached Alfonsín and most did not receive a response, though all were stamped with the date of receipt, assigned a file number, and, depending on their content, summarized by secretaries and sent on to the corresponding national, provincial, or municipal agency. However, the epistolary trail often ended there. One of the few letters to receive a personal response from the office of the president was from Gummi Industries, a car parts manufacturer, informing the

33. "Bankers Worried about Losses on Argentine Loans," The Washington Post, March 6, 1984, p. Al.

34. In late September 1984, Argentina reached a preliminary agreement with the IMF and private lending banks, which issued four billion more dollars in loans. At the same time, private lending banks agreed to roll over more than $\$ 13$ billion in outstanding loans that were due in 1985. For more background on the 1984 debt negotiations, see Veigel, Dictatorship, Democracy, and Globalization, p.144.

35. AGN/DAI "Presidencia Alfonsín," leg. 90: 17349/84. María de los Remedios de Escalada de San Martín was the wife of independence leader José de San Martín. She galvanized the support of women from Mendoza to donate their jewels in support of the independence movement. 
president that its workers, "by spontaneous decision," had pledged one day's salary toward debt repayment. In addition, the letter continued, the company would donate an unstipulated amount every month "for as long as the country needed it." Attached was a check for 71,788 pesos made out to the Ministry of the Economy for "Debt Payment." The workers justified their contribution "[as] consequence of the spiritual state of the nation, unprecedented in the political history of our country and not seen since the days of National Organization." In response, the president's brother and personal secretary, Guillermo, thanked the workers and acknowledged the president was "deeply moved" by their gracious gesture. ${ }^{36}$

The letter arrived at the presidential offices in May 1984. By then, Alfonsín might well have been moved in other ways, as labor relations were irrevocably strained following the failure of a government-sponsored union reform law and escalating labor unrest, which would result in 13 general strikes by the end of Alfonsín's term. ${ }^{37}$ The Gummi letter also reflects a broader sentiment: at the onset of the Alfonsín presidency, national debt, which became a great burden on governability over the next two decades, was regarded as somehow manageable and disentangled from other realms of institutional life. "Pay, and it will be resolved," the letters seem to suggest. References to independence and nation formation cast debt as imposed from the outside, an external constraint, which unlike the internally polarizing military trials or labor reforms could unite disparate camps in common cause.

The return of democracy in 1983 represented a historic turning point for the nation. Letter-writers took seriously the promise of the new era and filled their messages with hopeful designs for the future. Citizen letters sent during the first two years following the return to democracy reflect understandings of a symbiotic relationship between political openings and economic recovery. In their messages of counsel and appeal, these early letters recall one of the founding principles of the return of constitutional government, which positioned democratic rule as the complete antithesis of Argentina's authoritarian past. From the onset of the campaign, Alfonsín and his advisors presented democracy as both salve and panacea for the economic and political

36. AGN/DAI "Presidencia Alfonsín,” leg. 8: 22028/84.

37. One of the first major legislative initiatives of the Alfonsín government was a plan to restructure the unions. The law, which was sent to Congress on December 17, 1983, became known as La Ley Mucci, after then Labor Secretary Antonio Mucci. The law's many provisions, which were meant to dilute Peronist control of the union movement, included open and public control of elections, decentralization, minority representation, and the breaking up of the newly reunited General Confederation of Labor (CGT). After months of debate, the law was rejected in the Senate in March 1984. It constituted a costly legislative defeat for the Alfonsín administration, leading to the replacement of Mucci. More importantly, it set the stage for a renewed Peronist block to emerge in the congress and increasingly tense relations between the government and union leaders for the remainder of Alfonsín's term. 
woes of military rule. They argued that if Argentina's economic and moral decline were the direct consequences of authoritarianism, it followed that political democracy would forge a new "social pact" to restore both financial and social stability. ${ }^{38}$ While the dichotomy between dictatorship and democracy originated in broader theories of Latin American democratic transitions, it resonated throughout Argentine public life, and had great implications for overall perceptions of the Alfonsín government, especially when it became clear that democratic restoration alone could not reverse all of the nation's fiscal woes. At the beginning of the administration, however, the tension between two seemingly antithetical political forms sustained widespread hope for the democratic horizons ahead.

\section{The Limits of Political Openings}

Between late 1983 and early 1986, a wave of public approval granted the Alfonsín administration a wide margin for managing internal and public rifts. ${ }^{39}$ The UCR won soundly in the 1985 midterm legislative elections, signaling confidence in the trajectory of the government. Yet, there were noticeable cracks in the democratic euphoria, especially in the fiscal realm. By April 1985, Alfonsín had outlined a new economic approach that prioritized reducing the fiscal deficit through cutbacks in public spending, the privatization of select state enterprises, and inflation controls. ${ }^{40}$ Important changes emerged in the ways that individuals thought about the prospects for the democratic future and their place in it. Despite optimism for the future, letter writers frequently highlighted the limited impact of national political openings on their lives. For many, the democratic return did not usher in the material changes that had fueled their expectations in 1983.

Petitioners often expressed their grievances in the form of complaint, a broad epistolary genre that spanned the decade and highlighted overlapping concerns

38. Kessler and Sigal, "La hiperinflación en Argentina."

39. Human rights groups paired disappointments over setbacks to justice with pointed criticisms of the administration's handling of the military and human rights policy. The movement galvanized support to pressure the government to make good on its promises to prosecute the crimes of the regime. Meanwhile, the first rumblings of military discontent struck an ominous chord for the fate of newly restored institutions.

40. Following a change in economic leadership in June 1985, the Alfonsín administration launched the Austral Plan, a heterodox "shock" program aimed at halting inflation and promoting economic growth and employment. The core of the plan consisted of a monetary reform through the creation of a new currency, the Austral. The currency cut three zeros off the peso, dramatically reducing inflation almost immediately. The plan also included other pro-market recipes: the central bank committed to curb bill printing, while overall state expenditures were cut from approximately 35 percent of GDP in 1983, to 28.8 percent in 1986. The plan was grounded in a system of price controls and income policies in the form of wage and tariff freezes and maximum price listings for basic foodstuffs. See Veigel, Dictatorship, Democracy, and Globalization, p. 152. 
about state services and the shifting economy. In 1987, a man named Eugenio seethed to the president as he recalled his quest to install and repair his home phone line. His letter included a dossier of bureaucratic travails, including attempts to contact the state phone company, politicians, even the federal police. "How can it be," he fumed, "that in full democracy NOBOD $\Upsilon$ has responded to or even acknowledged receipt of my request!" ${ }^{41}$ A similar letter from Velia describes her attempts to contact the municipal authorities, though under more tragic circumstances. Velia's 77-year old father had been killed in a hit-and-run accident as he crossed a busy intersection in Buenos Aires. When her letters to city officials went unanswered, she wrote to Alfonsín. "I am an Argentine citizen who awaited the triumph of democracy with much excitement," she began. "Thanks to Ex-Intendant Cacciatore," the military mayor of Buenos Aires most notorious for razing entire neighborhoods and expelling thousands of residents to make way for a massive highway system, her street had become a "death trap," with car races day and night and drivers using the zone as a freeway. With an elementary school located nearby and no synchronized traffic lights, Velia feared another accident. Her petition to make the intersection safer fell on deaf ears and in her mourning she endured a further setback: the woman who had hit her father turned out to be the girlfriend of a police captain. Frustrated, she pleaded with the president to intervene locally, signing her letter, "JUSTICIA!" 42

Velia is one of the few correspondents to allude to the policies of the military regime. For the most part writers did not cite recent history, though many of their grievances could be traced back to the deregulations set in motion during the dictatorship. Instead, they placed blame for current injustices in the immediate present-in the institutions and public offices that citizens interacted with on a municipal and neighborhood level every day. Jorge and Velia employed "democracy" as a rhetorical flourish to bolster their claims and to ground them in the moral language of the day. In doing so, they and many others may have believed their petitions would be taken more seriously. It is impossible to say with certainty if writers appealed to "democracy" because they thought that was what government leaders wanted to hear. Even allowing for that possibility, the urgency running through much of the correspondence reveals the ways that writers connected the democratic return to expectations of improvement in the material conditions of their daily lives. Concretely, democracy meant fixing traffic lights, installing phone lines, filling potholes, reopening factories in the industrial belt surrounding Buenos Aires, and fortifying sewage systems and water supplies. These were the tasks imposed by

41. AGN/DAI "Presidencia Alfonsín," leg. 90: 44199-9-0005.

42. AGN/DAI "Presidencia Alfonsín," leg. 35: 457/8324. 
writers on the Alfonsín government and the tasks on which it would ultimately be judged.

The realms of daily life emerge as key battlegrounds of democratic restoration. While many writers presented their demands as novel obstacles confronting the government, citizens' concerns were also rooted in the memory of democratic traditions forged over the course of previous decades. As Natalia Milanesio and Eduardo Elena have demonstrated, state policies attuned to consumption and public service first grounded democratic values and citizenship in the local and private sphere during the Peronist era (1945-1955) ${ }^{43}$ Despite opposition to Peronism itself, and the increasingly violent attempts by the armed forces to constrain political life, the social imprint of this period endured and influenced the democratic futures that citizens imagined for the rest of the century. The letters to Alfonsín concerning state services and infrastructure call to mind the letters sent to Juan Perón during the "Peron Wants to Know" campaign. As with the correspondence to Perón, in which citizens wrote in with their designs for the second Five-Year Plan, the letters to Alfonsín positioned individuals as direct participants in a national political project, but also identified the state as the legitimate entity for securing citizen well-being. Writers during the 1980s did not generally frame their correspondence as explicit dialogues with the past; however, the ideal democratic government that emerges through their letters can be traced back to the mid-century expansion of an interventionist benefactor state.

An increased frustration in the letters to Alfonsín over the course of the 1980s stems in part from a growing awareness of new limits on the state. Throughout the decade, streamlining the state was a continuous thread in public debate; it would provide an important route to achieving fiscal solvency, keep inflation in check, and reduce the public deficit. ${ }^{44}$ Although writers may have agreed on the need for state reforms, no clear consensus emerges from the letters regarding how that should occur. In their letters of complaint, petitioners painted a picture of a highly dysfunctional public sector in the throes of an economic tailspin. The daunting lines in government offices, excessive paperwork, and recalcitrant officials, long main tropes of the Argentine bureaucracy, were precisely what writers expected democracy to reverse. Yet, the correspondence illustrates a state that was at once omnipresent, yet inaccessible; demanding,

43. Natalia Milanesio, Workers Go Shopping in Argentina: The Rise of Popular Consumer Culture (Albuquerque: University of New Mexico Press, 2013); Eduardo Elena, Dignifying Argentina: Peronism, Citizenship, and Mass Consumption (Pittsburgh: University of Pittsburgh Press, 2011).

44. For more on the Argentine debates, see Rapoport, Historia económica, politica y social. For a regional view of these debates see Paul Drake, ed. Money Doctors, Foreign Debts, and Economic Reforms in Latin America from the 1890s to the Present (Wilmington, Del.: Scholarly Resources, 1994). 
yet unaccountable; interventionist, yet ineffective. Although some authors advocated privatization and outright dollarization of the economy, for many others the state remained a source of jobs and security. From 1983 to 1989, thousands of employment requests were remitted to ENTEL, the state phone company, and SEGBA, the utility company of Greater Buenos Aires. Nor did letters break down easily along class lines, with the upper-middle classes embracing structural readjustment, and lower-income sectors holding fast to the institutions and policies of the Peronist era. These ideas could exist together in seemingly contradictory ways.

A letter from Roberto, a father of four in Quilmes, a declining industrial town on the southern outskirts of Buenos Aires, exemplifies how citizens' engagement with the state was in flux during this period. Roberto advocated achicamiento del estado (shrinking the state) as the solution to Argentina's economic difficulties, a surprising proposal given that several paragraphs into his letter he introduces himself as a municipal worker. "I have given 30 of the best years of my life to the public sector," he declares, not without a touch of pride. Several features of Roberto's letter deserve mention: For one, Roberto's use of the phrase "achicar el estado" echoes the dictatorship-era economy minister, José Martínez de Hoz, who infamously proclaimed that his policies would shrink the state in order to agrandar la nación (shrink the state to enlarge the nation). In one sense, Roberto was in line with mainstream center-right economists and commentators of the day, including many members of the Alfonsín government. Yet, his solution to "shrink the state," far from suggesting a purge of the public sector, proposed special government-sponsored unemployment insurance and job-training programs to reposition municipal employees for work in state industries or the private sector. Roberto's letter hints at a moment during the 1980s when associations of privatization were still somewhat up for grabs, when "shrinking" could imply reform and the maintenance of the state as benefactor and prime employer-all this not long before the massive application of neoliberal structural adjustment in the 1990s. Roberto concludes his three-page letter with a thoughtful commentary, connecting the declining industrial economy of Quilmes to Argentina's position in the global economy: "I ask myself what our role will be in the future if our industry is practically destroyed and we are not in any condition to compete with Japan, Germany, the USA, etc. etc." 45

Like many other writers, Roberto acknowledges Argentina's diminished economic position and the realities of the crumbling manufacturing economy. 
Authors continually alluded to the fact that the dawn of the democratic era had coincided with a massive shift in national economic logics and identity, and they grappled with the interplay between internal and external constraints. A young man named Jorge wrote with a dilemma on December 10, 1984, the administration's one-year anniversary. At 23 , he had recently received his accounting certificate and hoped to marry and buy a house with his fiancée. "Like so many," he lamented, "we are unable to save money." Though they expressed a reservation about writing given "all of the problems facing the country," the young couple sought the president's counsel: "Our concern is this: our friends and acquaintances (people who call themselves honest!) advise us to invest in dollars. We think this is detrimental to national interests, despite the benefits it could give us, and we systematically refuse to speculate with this kind of 'investment.' I would like to know your response as the representative of national popular interests." 46

Upon first reading, Jorge's letter recalls national debt letters, acknowledging the interconnectedness of individual action and national economic well-being. But Jorge departs from the more positive implications of workers' donations and debt repayment. While debt may be imposed from outside, Jorge signals two internal threats: dollars and the "dishonest" citizens with the will to use them. More critically, the letter highlights a presumed incompatibility between "national popular" interests versus individual ones. Through polices of trade liberalization and repression, the military regime may have weakened the frameworks of state-led welfare and development-two cornerstones of what for decades constituted the national popular interest. However, the social recognition and articulation of that shift coincided directly with the return of constitutional government. Writers often expressed their dismay at the radical separation of national economic sovereignty from their individual security. "I did not speculate and look where it got me!" exclaimed an irate small-business owner as he recounted the rise and fall of his furniture factory and subsequent bankruptcy. ${ }^{47}$

Part of the Alfonsín government's mandate was to recuperate, recalibrate, and redefine the meanings of the "national popular." Throughout the 1980s, individuals struggled with their own definitions and repositioned themselves within altered political and economic landscapes. They did so as individuals and as citizens of a body politic. As the Alfonsín years wore on, however, the perceived antagonism of these spheres-the civic good versus individual advancement-became more rigid, to the extent that for many writers any hope 
for achieving a greater good would come at the expense of personal well-being, and vice versa.

\section{Citizenship and Human Rights}

Though one of the enduring legacies of the Argentine transition to democracy is human rights policy and the effort to end the impunity of the armed forcesfrom the much lauded Nunca Más report and the groundbreaking trials of members of the military regime to the equally criticized limitations on legal proceedings-these events are strikingly absent from the correspondence to Alfonsín. ${ }^{48}$ While the president did receive letters and telegrams following military uprisings, and messages of moral outrage following the passage of laws to put an end to military trials, the epistolary silence is deafening in view of the scholarly attention paid to these events during the Alfonsín presidency and beyond. One important qualification is necessary at this point: with respect to human rights, individuals could mediate their concerns through activist networks and institutions, to the extent that a letter to Alfonsín was in contrast an unlikely, and comparatively ineffectual, venue of protest or support. Petitioners often highlighted their inclusion as part of the "unaffiliated" masses, a status that not only justified unmediated contact with the president, but also distilled petitions to a pure state of need, opinion, or praise, seemingly impervious to outside political or ideological influences. This is not to argue that human rights were not a social concern of "ordinary" Argentines during the 1980s. On the contrary, the letters demonstrate a multivalent notion of human rights, transformed into ideals along the lines of Velia's call for justice following the death of her father. Taken as a whole, letter-writers articulated a definition of citizenship grounded in a holistic notion of human rights, which afforded all Argentines guarantees of material and physical security.

Rights language penetrated social life, and was refitted to highly charged conceptions of home and national belonging, among others. The tensions between personal prosperity and the nation's democratic future emerge forcefully in letters from individuals contemplating emigration or recently returned from abroad. Educated professionals with the training and means to look for work overseas began sending their descriptions of the difficult decision to leave Argentina as early as February 1984, two months into the administration. Susana was a young newlywed when she left Argentina in the early 1970s, "facing economic impossibility, and the uncertainty of those

48. Elizabeth Jelin, "Los derechos humanos: entre el estado y la sociedad," in Nueva Historia Argentina, vol. 10, Dictadura y Democracia (1976-2001), Juan Suriano, ed. (Buenos Aires: Editorial Sudamericana, 2005), pp. 507557. 
days, never knowing where another bomb was going to go off." Following several years in Venezuela and the United States, she and her family settled in Italy before returning to Argentina following Alfonsín's election, happy at the prospect to "do something for the country." Shortly after her return, however, she wrote of her difficulties in finding a job, lamenting that, "little by little, we have begun to look abroad again . . . and I believe there are many of us in the same situation." 49

Susana acknowledges membership in a wider community originally forced abroad by a combination of political violence and lack of opportunity. While the risk of "bombs going off" might have dissipated, Susana saw that threat as having been replaced by equally destabilizing economic forces that were conspiring to push her and her family out again. Silvia, a 34-year old architect, wrote Alfonsín upon her return from six years in Italy with a similarly blunt assessment: "Mr. President, I have heard you say that the political exiles can come back with guarantees of work, security, and stability, but what about the economic exiles?"50 Susana and Silvia's reference to violence and exile, a highly charged combination with its connotations of state terror and victimization, is striking. In their appropriation of the language of human rights, they identify themselves as casualties of the dictatorship and therefore entitled to guarantees of justice and redress.

Citizens framed demands for economic justice and social well-being as human rights at the heart of the democratic restoration. At the same time, the language of human rights afforded individuals new ways to talk about and assert their views regarding much older struggles. Rights claims were particularly evident in messages from citizens outside of the middle class, who wrote of their ongoing fight against poverty. In 1986, Marta, a single mother of three, wrote of her six-year attempt to fight eviction and secure housing for her family in Córdoba and Buenos Aires. Toward the middle of her letter, she addresses the president very directly: "I believe that if your heart has feeling enough to bring back all of the exiles, then you could also save us from the exile we were sent into by human insensibility. That would give us the chance to believe that Justice really does exist." ${ }^{51}$ Marta described her own internal exile- - an endless saga of cancelled social worker visits and unscrupulous landlords-as a severing from the institutions meant to help her. That sentiment is echoed in a hastily written message from Zulema. Writing from "the entrance to the Tribunales court" in the center of Buenos Aires, where she was attempting to contest an eviction

49. AGN/DAI “Presidencia Alfonsín,” leg. 269: 109639.

50. Ibid., leg. 3/8/11: 10794/84.

51. Ibid., leg. 3/8/11: 10815/84. 
notice, the urgency of Zulema's letter is palpable: "Please, please, we need 90, 60 , even 30 days to find a new place to live." As she explained, the letter was her last-ditch effort to help her family: "Mr. President, I am turning to you because I know that you are a very Humane person, and that this is a Human Right .. . Now that we live in democracy, how can our children live in the streets?" 52 Thus, human rights redefined citizenship during the 1980s, placing in greater relief the injustices against which the new democracy was measured. Yet, individuals directed their demands for the human rights to a home, food, and employment, among others, to a state that was increasingly unable to follow through on the original promises of the democratic era.

\section{Remaking Democratic Expectations}

By 1987, the Alfonsín administration was embattled. The early gains of the Plan Austral, the economic plan instituted in 1985 that dramatically reduced inflation, began to falter. As the price freezes originally implemented by the plan were gradually lifted, inflation rose steadily, cresting at 175 percent at the end of the year-more than double the rate in 1986. Then, during Holy Week, the carapintadas, military officers threatened by the ongoing prosecution of the armed forces, made their debut in a dramatic takeover of the Campo de Mayo military base. Though the tense four-day standoff ended peacefully, Alfonsín quickly came under fire following the passage of the Due Obedience law, which absolved many lower-ranking officials from trial. The turbulent year culminated politically in the midterm elections of September 6, 1987, which swept the Peronist party into congressional control and into the governorship of key provinces, Buenos Aires included.

Following Peronism's first-ever electoral defeat in the 1983 presidential elections, the party entered a period of dramatic flux and began a steady transformation from its traditional union base into a locally based "party of the poor." 53 The 1987 electoral victory marked the movement's resurgence and its incipient overhaul. In the wake of the midterm elections, the Peronist win emerged as a turning point with significant implications for the UCR government. Letters sent by self-proclaimed Alfonsín supporters and Radical party members emphasized negative depictions of Peronism, contrasting the "corrupt" Peronists to the stately and inherently "democratic" Radical party. For example, a woman named Norma wrote a brief letter, in which she

52. Ibid., leg. 417- 116397.

53. Steve Levitsky, Transforming Labor-Based Parties in Latin America: Argentine Peronism in Comparative Perspective (New York: Cambridge University Press, 2003). 
concluded, "As we all know, the Peronists are people of bad character (mala calaña)." ${ }^{54}$ Others, like Elsa, framed the Peronist resurgence as proof of "a lack of civic maturity." 55

Yet, even the president's most sympathetic admirers characterized the Peronist win in terms of a UCR failure in the economic sphere. Fiscal recovery, combined with an ambitious social agenda, was part of the administration's mandate from the beginning, and the September 1987 elections reflected an overall perception that the administration was falling short on both fronts. Pedro, a life-long Radical, sent his detailed analysis of the election results, including a vehement critique of internal UCR structures and tensions among party leaders and their effect. However, Pedro believed the UCR loss was rooted even more in "the gap between our basic needs (canasta familiar) and our salaries." "Mr. President," he reasoned, "you know that the flood of votes that went to Peronism was based on daily life (pasa por lo cotidiano)." "56

Another message, from a pensioner named Eduardo, reflected the ire of one sector of the popular classes that had originally supported Alfonsín. Writing from the southern belt of Greater Buenos Aires, a region that experienced a wave of factory closings and capital flight throughout the 1980s, Eduardo blamed Alfonsín for abandoning the working class. As proof, he enclosed a series of articles from local newspapers chronicling the plight of pensioners from his area, including a graphic photo of an elderly man who starved to death alone in his house. The photo's caption read, "Hunger: The Cruelest Battle!" Eduardo feared the same fate and vehemently analyzed the downturn of popular support for the government: "You have forgotten about the workers and the pensioners! We are hungry! And that is the reason why we changed our position in the last election. We cast our 'voto castigo' against the policies of your government, especially economic and social policies." 57

Despite their contrasts in tone, Pedro and Eduardo's letters echo shared opinions of government shortcomings and dashed hopes. Their messages, and others like them, are also are signposts of the failure of the Alfonsín government's initial attempt to reconcile the "liberal republic" and the "popular republic," an attempt rooted in the democratic traditions of Yrigoyen and Perón. In the year and a half that remained of the Alfonsín administration, economic recovery would become the principal benchmark for measuring democratic solvency. Indeed, in the wake of the events of 1987, writers seemed

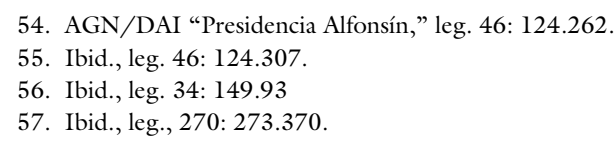


to abandon the notion that the government could implement the social change that had fueled hopes at the onset of the administration. As inflation rose and daily life became ever more expensive, many argued that the future of the Alfonsín government depended solely on fiscal recovery. In their letters, economic stabilization tended to be equated with democracy itself.

As voters were setting their sights on the May 1989 presidential election, the year began with a turbulent and bloody start. In late January, 70 members of the armed group Moviemiento Todos por la Patria (MTP) stormed the La Tablada barracks on the outskirts of Buenos Aires amid growing rumors of another military uprising. By the time the bloody confrontation ended the following day, 29 MTP members were dead and 13 more were in custody. ${ }^{58}$ Not two weeks after La Tablada, the government's most recent economic stabilization plan collapsed following the World Bank's decision to cut off promised credits to Argentina. The bank's announcement sparked a prolonged bout of hyperinflation that did not let up fully until July. Between January and May 1989, the price of some basic food goods rose as much as 1000 percent. ${ }^{59}$ In late March, the governor of Buenos Aires declared the province in a state of emergency. He sent an urgent telegram to Alfonsín to authorize the distribution of emergency food subsidies "in order to avoid the coming social chaos." ${ }^{60} \mathrm{By}$ the end of the year, inflation would reach an eerie $4,923.6$ percent. $^{61}$

Alfonsín addressed the opening session of Congress for the last time as president on May 1, 1989. As the economy continued its downward spiral, it seemed certain that Carlos Menem, the Peronist governor of La Rioja, would easily beat the UCR candidate, Eduardo Angeloz, who was governor of Córdoba. From the congressional pulpit, Alfonsín could not ignore this fact, or the social havoc wrought by months of hyperinflation. Recalling the milestones and setbacks of his presidency, Alfonsín emphasized that his greatest accomplishment was perhaps his very presence in Congress that day-no small feat, given that he was poised to transfer constitutional power to a democratically elected president for the first time in five decades. He concluded his speech in a way that belied the letter-writers' deep concerns, stating, "We have been so successful that the country seems to have forgotten what our main concern was in 1983. Today it seems natural that a government is able to fulfill its constitutional mandate." 62

58. Claudia Hilb, "La Tablada: el último acto de la guerrilla setentista," Lucha Armada en la Argentina 9:3 (2007), pp. 4-22.

59. Sergio Serulnikov, "When Looting Becomes a Right: Urban Poverty and Food Riots in Argentina," Latin American Perspectives 21:3, Social Movements and Political Change in Latin America (Summer 1994), pp. 69-89.

60. AGN/DAI "Presidencia Alfonsín,” leg. 20: 154.003.

61. Rappaport, Historia económica, politica y social, p. 707.

62. Raúl Alfonsín, presidential message to the 107th Legislative Assembly, May 1, 1989, http://lanic.utexas.edu/larrp/pm/sample2/argentin/alfonsin/893875t.html, accessed January 9, 2015. 
Letters flooded the presidential palace in the wake of the address. Echoing Alfonsín's assertion, writers commented on the ways that political democracy had indeed achieved a "commonplace" or "natural" status in their lives. However, that certainty came at the expense of a radical redefinition of their expectations of just six years earlier. One of the letters sent to Alfonsín during his final months in office was from María Luisa, who for the past six years had often been "tempted to write of the incredible hopes that I had for my country, my compatriots, and for my children." Though María Luisa wrote with pride that her children now lived in a "free country," her letter concluded with a bittersweet assessment: "But the years went by, and though I still think and believe that this is the best system of government, we have reached a desperate situation, Mr. President. How can you live if you cannot buy the necessities of life?" 63

While María Luisa's doubts were intertwined with esteem for Alfonsín, other individuals were less sympathetic. Lucía wrote from Lomas de Zamora, in the south of Buenos Aires, shortly after the May 14 elections in which Menem soundly defeated Angeloz of the Radical Party with close to 48 percent of the vote. Though Lucía was certain that "[democracy] was the best political system," she declared that "our situation has become intolerable." Her descriptions vividly capture the impact of economic crisis in Greater Buenos Aires, from the empty shelves in her local supermarket to the rising cost of medicines - "when they are available" - to the suspension of her mother's pension, to the general deterioration of her town center. As she looked at her surroundings, she blamed public officials for the crisis and degradation of her town: "Every day we hear talk about public spending! So let's put public officials to work! Repairs, cleanups, just stop throwing money away!"64

Both Lucía and María Luisa recognized political democracy as a basic fact of their present reality. Yet in taking stock of their lives over the past six yearsMaría Luisa in resignation, Lucía in anger-the women had let go of a belief that their material well-being could and would be safeguarded by the same democratic government that was able to secure them other political freedoms. Read together, their letters lay bare the great transformation of democratic expectations from 1983 onward. At the start of the Alfonsín administration, the main tenets of liberal democracy and human rights were melded with a firm commitment to social justice and economic redistribution. Though not without its strains and cracks, that vision encompassed both the hopes of letter writers and the promise of the newly restored constitutional government. Endemic

63. AGN/DAI "Presidencia Alfonsín," leg. 20: 153.560.

64. Ibid. 
economic crisis and disenchantment with government policy, followed by the upheaval of hyperinflation, ultimately decoupled or unhinged the constituent parts of an inclusive and ambitious democratic agenda. Together, Lucía and María Luisa highlight what they saw in May 1989: the uncomfortable distance between political democracy and social rights in the midst of economic tailspin. However, the push for social justice and the demands it generated never disappeared. On the contrary, social demands became even more acute, and letter-writers placed in relief faltering welfare programs and a state ill equipped and unwilling, in their eyes, to address increasingly critical need.

Lucía wrote her letter on May 29, 1989. The next day she may have awoken to news that in the neighboring town of Quilmes' supermarkets were being ransacked by "roving bands" of looters-alternately identified by the local newspaper, El Sol, as mothers trying to feed their hungry children, or leftist agitators-who were holding defenseless owners hostage and emptying store shelves in the process. ${ }^{65}$ Over the preceding five days, similar reports had poured in from the outskirts of Rosario, Córdoba, and other parts of Greater Buenos Aires, accompanied by rumors of escalating street violence, food shortages, and supermarkets in flames, which placed entire communities on edge. In response to the social unrest, Alfonsín declared a 30-day state of siege. The lootings, which were most widespread in Rosario, resulted in 15 deaths over the course of nine days. In light of the chaos and an economic situation that had become untenable, Alfonsín, who for several days had firmly denied reports that he would step down, announced his decision to transfer power to Carlos Menem five months earlier than anticipated. ${ }^{66}$

One of the letters written to the president during his final days in office was from Graciela, a teacher in Greater Buenos Aires, who perhaps expressed best the arc of the Alfonsín years, "I agree when people say, because it hits close to home, that 'liberty won't feed you.' But freedom still tastes pretty good.” As Graciela wrote "from her kitchen table before heading off to class" in late May 1989, she wove her personal history and her hopes and desires for Argentina into a forceful and prescient glimpse of the nation's future: "I would prefer to not wake up

65. “'Robamos para darles comida a nuestros hijos,' dicen saqueadoras de Quilmes”; “Saqueos: acusan a la extrema izquierda," El Sol, May 30, 1989.

66. Menem was sworn into office on July 8, 1989. The former governor of La Rioja province ran on a promise of a "productive revolution," in concert, at least rhetorically, with his Peronist roots. Yet upon taking office he immediately set out to undo the legacy of his party. In April 1991, the third minister of the economy, Domingo Cavallo, set in motion "the miracle of the 1990s." His economic plan, known as "convertibility," pegged the peso to the dollar. For a time, the plan resulted in average growth rates of 8 percent a year and a boom in consumer spending power. But by then the government had already begun selling off its main assets to foreign investors, privatizing, among many other the gas, telephone, airline, postal, water, subway, railroad, and electric utility sectors. Market freedom, however, came at a considerable cost, undoing what remained of social welfare programs and the benefactor state. As the public sector was purged, labor rights were dismantled, sparking the growth of an informal economy and massive inequalities. 
every morning to hear about rising prices, the exchange rate, and shortages. I want economic stability, security, and national progress, but I don't want to achieve that by paying the social costs of those great powers people consider 'Promised Lands.'. . . I want PEACE above all, in all its significance." ${ }^{67}$

\section{CONCLUSION}

This article has traced the restoration of constitutional government in Argentina as it emerged through citizens' letters to Raúl Alfonsín. As writers inscribed themselves as part of a new national project, they tested revived public languages of democracy, human rights, and justice, even as they lay bare the growing distance between their expectations and their daily lives. Military trials and labor reforms have received much attention as the sources of greatest achievement and chaos over the course of six dramatic years, during which the survival of the Alfonsín government was in doubt more than once, beset as it was by 13 general strikes, armed insurrections, and bitter reversals of justice. The letters to Alfonsín are imbued with these events, but they were often not at the center of writers' concerns as they sat down to type or fire off a handwritten message. In the midst of overlapping political openings and economic retreat, Argentines' calls for constitutional restoration were ever more deeply rooted in the hope for justice following the end of a brutal period of military repression, and in the promises of state-led welfare, originally forged at mid-century. The main historical reference point for letters writers was not necessarily the immediate authoritarian past, but rather the memory of the benefactor state that had emerged during the Peronist period. Despite the violence of military rule, which attempted to undo the foundations of state-led welfare, the legacy of previous democratic struggles remained intact and formed the basis of social expectations for the transition to democracy.

The letters to Alfonsín inspire new interpretations of Latin America's constitutional restorations by grounding letter-writers' concerns within much longer-running contests over the meanings of democracy and citizenship that marked the twentieth century. During the 1980s, human rights redefined citizenship. Writers framed their demands as human rights for social wellbeing, which they attached to claims for home, employment, food, and national belonging, among others. Through their messages to the president, citizens expressed their grief at seeing the constituent parts of an initially optimistic and holistic definition of democracy come undone through years of economic crisis, military unrest, and growing social inequality. Letter-writers gradually

67. AGN/DAI "Presidencia Alfonsín,” leg. 274: 152.774. 
relinquished their beliefs in a state that could guarantee both political rights and their material well-being. Though the transition was heralded as a break with Argentina's past, writers also struggled to make sense of the continuities, and the extent to which 1983 represented the end of entrenched cultural conflicts, a radical redefinition of those conflicts, or a mere interlude in them. The letters to Raúl Alfonsín narrate a history of diminished hopes, and the narrowing of possibilities over the decade. Yet the popular record of Argentina's democratic transition that they provide also restores a sense of process and specificity to political debates of the 1980s, and the multiple attempts to reconcile a historical tradition of Latin American social rights with the coming post-Cold War and neoliberal age.

Fairfield University

JENNIFER ADAIR Fairfield, Connecticut $<$ jadair@fairfield.edu $>$ 